\title{
THE PEOPLE'S PERCEPTIONS ON AESTHETIC AND USES OF THE ACTIVE URBAN PARKS IN SURABAYA
}

\author{
KWANDA, Timoticin ${ }^{1 *}$, KARTONO, Lukito ${ }^{1}$, WONOSEPUTRO, Christine ${ }^{1}$ \\ ${ }^{1}$ Department of Architecture, Petra Christian University \\ Jalan Siwalankerto 121-131, Surabaya 60236, INDONESIA \\ E-mails: 1kartono@petra.ac.id; christie@petra.ac.id \\ * Corresponding author: cornelia@petra.ac.id
}

\begin{abstract}
Urban open space namely urban parks in Surabaya are a recent phenomenon that advocated by the recent mayor to provide outdoor recreation for physical welfare of the people. So far, however, no information was found regarding perception of the people on condition of the urban parks, which is a first step to improve the urban parks. The objective of this paper is to examine the perception of the people toward the urban parks in Surabaya, in specific to what extend the provision of the parks meet the needs of the visitors. Five urban parks were surveyed, and data were collected through observation, documentation, and distribution of questionnaires that conducted in April 2014. As a result, based upon the surveys, most of the visitors (78\%) perceived the 5 parks are good places to be visited that perceived as clean (74\%), save (76\%), gorgeous (78\%), and adequate availability of amenities (66\%). In this sense, this good perception of the parks is a result of emphatic actions in designing the parks that emphasis on the needs of visitors. Nevertheless, in the future, many of the visitors (54\%) hope that the amenities in the parks have to be improved.
\end{abstract}

Keywords: Perceptions; aesthetic; uses; active parks; and Surabaya.

\section{INTRODUCTION}

Urban open spaces represent a significant resource in a city whether viewed in terms of green area, or recreation area. Urban open space is defined as areas generally free from development or developed with low intensity uses that respect natural environmental characteristics. They are used for purposes such as preservation of natural resources, outdoor recreation, scenic and visual enjoyment. In 2011, Surabaya with an area of 33,048 ha, green open space such as cemetery, sport areas, lakes, reservoir, forest is 6,678 ha or $20.21 \%$ of the total area, but active urban parks comprise only for $5.64 \%(1.863,64$ ha) of the total green area. These eleven urban parks are distributed across the whole city equipped with recreation and sport amenities for diverse needs of the community (Dinas Kebersihan dan Pertamanan).

Some of the parks, such as Bungkul Park, have won the 2013 'United Nations Asian Townscape Award,' to honor cities, regions, projects, that have played a significant role as models in landscape construction. The Bungkul Park became the only city park in Indonesia that won a number of awards including the 'ASEAN Environmentally Sustainable City Award 2012' and, the 'Best City Park in Indonesia Award,' and as well as the 'C2C Award for Participation 2012' in Asia Pacific that given to Surabaya for the participation of all stakeholders, such as government, private sectors, academics and the community in developing the city.

In Surabaya, the parks is one of the most popular recreation activities, as the survey revealed that $80 \%$ of the people interviewed has visited the urban park for once to twice in a week (figure 6). Recently, however, no attempts have been made to collect information on how emphatic the urban parks through the visitor's perception on this substantial urban resource, the urban parks in Surabaya.

This paper attempts, firstly, to provide an overview of urban parks, tracing their development. The latter, more than half of the paper then sets out what are people's perceptions on these urban parks, to what extend emphatic actions through the provision of the parks can fulfil the need of the visitors in term of aesthetic such as beauty and cleanliness; and function, such as accessibility, safety and amenities of the parks.

\section{ACTIVE URBAN PARKS}

Public space is understood as a gathering space for commonly shared by the public for open usage such as streets (linear types), including the pavement, town squares or parks. Active parks could be defined as taking decisive actions in designing parks that emphasis on the needs of visitors of the parks in term of their aesthetic including cleanliness, and uses or 
functions, such as accessibility, safety and amenities. In term of accessibility, active urban parks are designed for a public space that every person has a right to access, and to use the parks, to perform desired activities (Carr, 1992). In this sense, active urban parks are for every person with different backgrounds in term of education, occupation, age, gender, and physical conditions namely disabled people. As active urban parks, the urban parks not only can be accessed and used by any individual, but also it is intended for the women as the marginal group, the elderly and disable as 'the forgotten', and children as 'the silent' group (Badshah, 1996). According to Edwards \& Tsouros (2006) as stated that 'low income tend to be less active in their leisure time because they are less able to afford and access programs and facilities ....' In this sense, the local government aims at promoting physical activity among people of all ages, in all social circumstances, through providing active parks for the disadvantaged people in Surabaya, as certain groups are particularly vulnerable to social exclusion, including young people, older people, and people with disabilities. In short, an active urban park is a park that used for physical activities, such as walking, cycling, exercising for pleasure and fitness, participating in sports, and playing.

To understand or to what extend active urban parks in Surabaya have fulfilled the need of the visitors in term of aesthetic and functions, a survey was carried out to know opinions of the observers based upon a reading on the urban parks. Gibson (1966) argues that perception is direct, as there is enough information in our environment to make sense of the world in a direct way. In other words, what you see if what you get, thus there is no need for processing (interpretation) as the information we receive about size, shape and distance is sufficiently detailed for us to interact directly with the environment. In this sense, perception is defined as awareness and opinion of an observer based upon a reading or view on an object, in this case an urban park.

\section{RESEARCH METHOD}

Much of the material in this paper is drawn from distribution of questionnaires, field observation and documentation with photo and video recording on the five (5) urban parks in Surabaya. ${ }^{1}$ The five urban parks were selected in term of their uses as active

\footnotetext{
${ }^{1}$ Unless stated otherwise, tables and figures used in this paper are produced by the author.
}

parks based on a preliminary survey. The use of photographs as the evidence for evaluation is a compliment to direct observation. Field observation is needed where certain activities are really only evident when directly observed, which not always captured in a photograph. The field survey was conducted in April 2014, namely on April 2 and 22 (weekdays) and April 9 (holiday) for Friendship Park, on April 13 (weekend) for Flora Park, on April 4 (weekday) and on April 5 (weekend) for Bungkul Park, on April 4 (weekday) and April 5 (weekend) for Elderly Park, and on April 2 and 18 (weekdays) for Fruity Park. Weekdays and weekends were selected on purpose to have a whole representation of the visitors at the parks.

Ten visitors at each urban park were surveyed with a questioner form comprise of ten questions that structured into three main issues, such as (1) demographic data; (2) perception on the urban parks in terms of aesthetics such as cleanliness and beauty, and uses such as access, safety and facilities; and (3) their suggestions to improve the urban parks. Finally, the result of the surveys will be tabulated for descriptive statistics analysis and interpretation.

\section{URBAN PARKS IN SURABAYA}

This section examines the recent formation of urban parks in Surabaya in an attempt to identify the motives and forces that prompted the provision of the urban parks. In Surabaya, from the earliest times urban open space has been a part of the urban fabric. In the oldest part of the city, the European quarter at the northern part, in eighteenth century open space had been formed as part of the urban formation. In 1940s, in the southern part of the city, Bungkul Park was formed in the Darmo residential area. After the independence in 1945 to 2006, open space remain the same as open green space, no efforts were made to create the open space become active urban parks for recreations and sport activities.

Since 2007, however, the mayor's passion for parks, Tri Rismaharini, arises from her time as head of the city's Municipal Environment and Sanitation department. Since then, she was working hard to add more open space into active open green space. In 2007, the city government was active in rejuvenating the city's parks including turning many derelict plots and gas station into active green open spaces. There are now eleven parks in Surabaya with different themes, such as Fruity Park (Taman Buah), Friendship Park (Taman Persahabatan), Elderly Park (Taman Lansia), and Flora Park (Taman Flora). These parks are also equipped with Wi-Fi, library, 
outdoor sports and facilities for people to fully enjoy the park (table 1).

\section{Bungkul Park}

The park is located in Darmo Street, a major road in Surabaya next to a walled cemetery complex of a local Islamic religious leader the so-called Mbah Bungkul which some locals visit to pay respects. This $15,483 \mathrm{~m}^{2}$ urban park is one of the largest parks in Surabaya, some of the area namely $900 \mathrm{~m}^{2}$ was designed and opened on March 21, 2007 for sport, education, and entertainment and equipped with various features for physical exercises and recreation. The park is divided into 4 areas, the main area in the northwest has a round shape amphitheater for sport activities, music and art performance (figure 2). At the southwest side, there is a bicycle BMX track, children's playground namely slides and glides, swings, seesaws, and skateboard arena. In the northeast area is used for culinary spot with various food sellers selling many kinds of food and drinks. The old cemetery is located at the southeast of the park.

The park is equipped with a jogging track, Wi-Fi Internet access, and a path for disable people to enjoy the park. Every weekend, such as on Saturday, when the field observation was conducted, many families visited the park with their children for recreation, the parents were sitting to watch their children playing and walking around the park for healthy walk and visual enjoyment (figure 1). At night, it has very sufficient lighting all over the place, so many people stay until late night.

\section{Flora Park (Taman Flora)}

This $33,810 \mathrm{~m}^{2}$ park is opened to the public in August 2007. During the field observation on Sunday, the park was vibrant for its diverse green with a lot of trees, a mini zoo with some animals such as deer, a bird park, a fishpond, some playgrounds, outbound activities such as robe and trees climbing, and people were sitting on the grass under the shade of trees nearby, enjoying the cool breeze and chirping birds (figure 2). In the centre of the park, a pavilion of $5 \mathrm{~m}$ $\mathrm{x} 10 \mathrm{~m}$ building is provided for music and art performance. On November 28, 2012, the park was launched as a learning center to campaign programs on health, cleanliness and environment to the public through various students' activities, and exhibitions. It is equipped with computers and Internet lines for public learning to access information and entertainments, and training on information technologies.

\section{Elderly Park (Taman Lansia)}

Lansia, literally is old people, thus Lansia or Elderly park is design especially for senior citizens. The park with $2,000 \mathrm{~m}^{2}$ is also used to be a gasoline station which then transformed into a green park with trees and grasses, playgrounds with swings and slides, sitting area, a water fountain, garbage bins, and a security post (figure 3). The park, which has most visitors in the afternoon, has a long jogging track and reflexology walking paths. A number of green benches are placed around the park, allowing visitors to sit comfortably. A particular path is provided for access of disable people. During the field observation conducted on Friday and Saturday, the park was fully visited by people, it was dominated by adults on Friday and dominated by children who came with their parents on Saturday.

\section{Friendship Park (Taman Persahabatan)}

This 2,259 $\mathrm{m}^{2}$ park was used to be a gasoline station which then in 2007 it was transformed into a green park with 50 kinds of flowers, trees and grasses and sitting areas, playgrounds, jogging track, a walking path, a pond and fountain, and a skateboard arena. This park has a distinct feature with six special trees planted on July 23, 2007 by the mayor of 6 cities such as Batam, Bandung, Banjarmasin, Sidoarjo, Yogyakarta, and a city from Japan, Kochi.

These trees, the so-called 'Friendship Trees' planted between the mayor of Surabaya and the other six cities are a symbol of friendship (figure 4). Some replica of sustainable city awards given to the city such as Wahana Tata Nugraha and Adipura Kencana are displayed in this park. During the field observation was conducted on Wednesday, and Tuesday, the park was not fully occupied by visitors, however on holiday, on April 9, 2014, the park was full of visitors enjoying the various features in the park.

\section{Fruity (Park Buah)}

Buah is literary fruits or fruit park that used to be a gas station, transformed into an active park donated by a bank, and opened in August 18, 2009. The park with $1,375 \mathrm{~m} 2$ is a green open space with flowers for visual enjoyment and equipped with two pedestrian tracks, playgrounds with fruity forms such as slides, glides, swings, seesaws; lamps and seats with three fruity forms namely banana, papaya, and star-fruit; a fountain, motorcycle parking area, garbage bins, security post, and Wi-Fi network. On weekdays such as Wednesday, the park was mostly unoccupied by 
Table 1. The List of the Urban Parks in Surabaya

\begin{tabular}{lcccl}
\hline \multicolumn{2}{c}{ Name of the parks } & Year built & Area (m2) & \multicolumn{1}{c}{ Amenities } \\
\hline $\begin{array}{l}\text { Bungkul } \\
\text { street }\end{array}$ & Park, Darmo & 2007 & 15,483 & $\begin{array}{l}\text { Amphitheatre, BMX bikes lane, skateboard arena, jogging track, Wi-Fi } \\
\text { Internet, playground area such as slides, glides, swings, seesaws, sitting } \\
\text { area, a fountain, feet rubbing pathway for reflexology, disable people } \\
\text { pedestrian path, and food stalls. }\end{array}$
\end{tabular}

Flora Park, Bratang street

Elderly Park, Kalimantan street

Friendship Park, Sulawesi street

Fruity Park, Undaan street
33,810 A green park with a lot of trees, a mini zoo with animals such as deer, a bird park, a fishpond with a fountain, playgrounds, outbound activities such as robe and trees climbing, sitting area, and a pavilion provided for music and art performance.

2,000 A green park with trees and grasses, playgrounds with swings and slides, sitting area, a water fountain, feet rubbing pathway for reflexology, a pedestrian path for disable and old people.

2,259 A green park with 50 kinds of flowers, trees and grasses and sitting areas, playgrounds, sitting area, jogging track, and a walking path, skateboard arena, and six 'Friendship Trees' planted by the mayor of Surabaya and the 6 other mayors as a symbol of friendship.

1,375 A green park with flowers for visual enjoyment that equipped with two pedestrian tracks, playground with fruity forms such as slides, glides, swings, seesaws; lamps and seats with fruity forms namely banana, papaya, and star-fruit; a fountain, parking area, and Wi-Fi network.

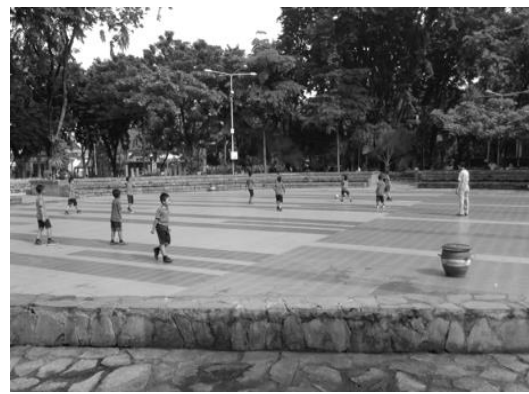

Amphitheatre

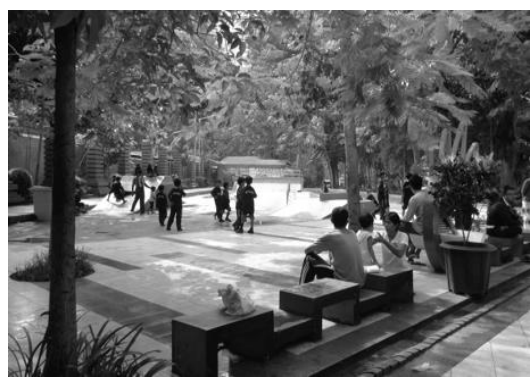

Seating area

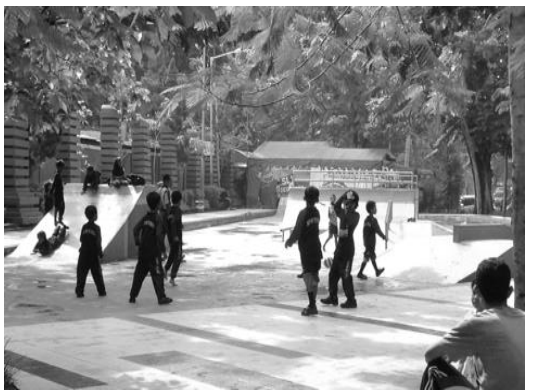

Skateboard arena

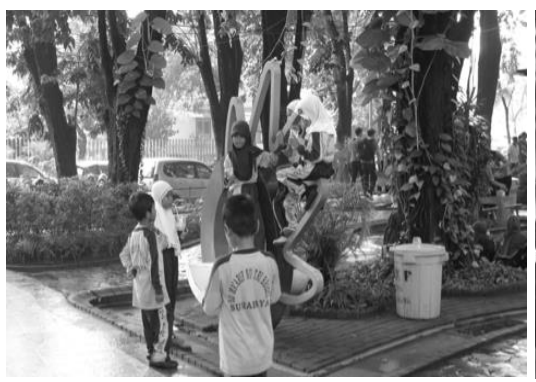

Playground area

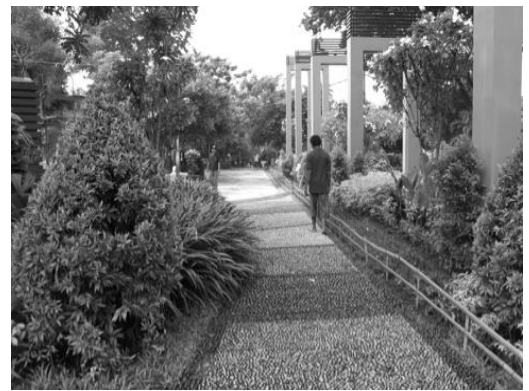

Pathway for feet reflexology

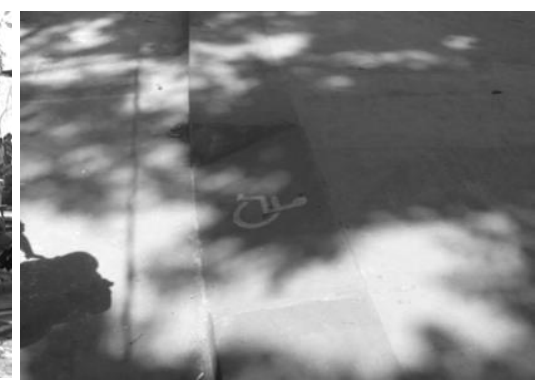

Disable access to the park

Figure 1. Bungkul park is equipped with amenities such as amphitheatre, and skateboard arena

visitors, when the field observation was conducted, however on Friday afternoon, at the second field visit, many families visited the park with their children, while the parents were sitting and walking around the park for visual enjoyment and exercises, their children were playing (figure 5).

\section{THE ACTIVE URBAN PARKS IN SURABAYA}

Opinions of the visitors were surveyed, and the result shows on the five parks:

- The parks are popular destination that visited by $80 \%$ of the respondents once to twice a week. 


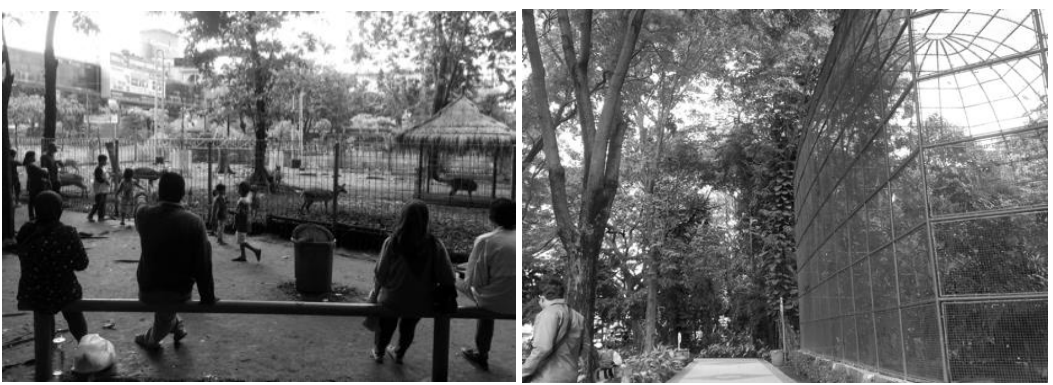

A mini zoo

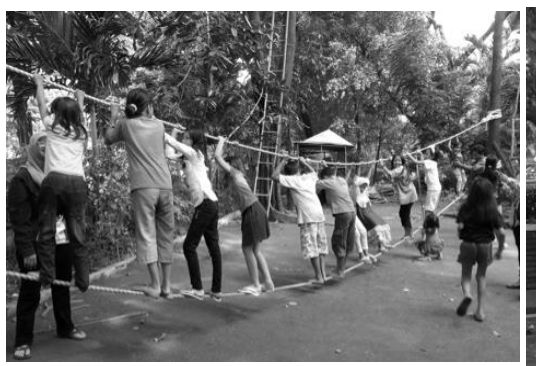

Outbond area
A bird park

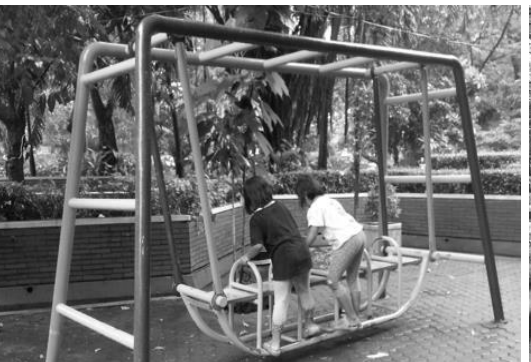

Playground

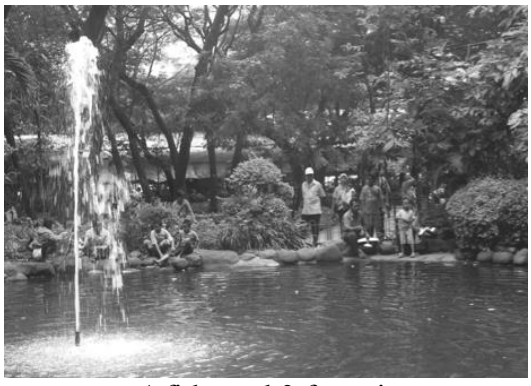

A fish pond $\&$ fountain

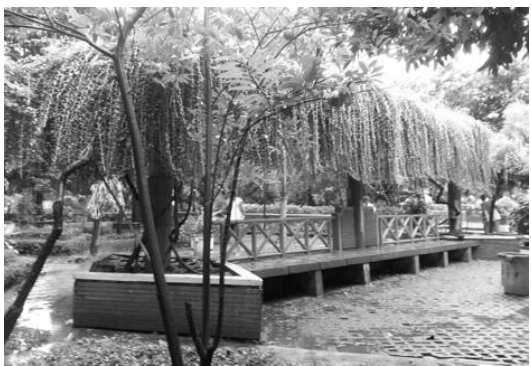

Seatting area

Figure 2. Flora Park is equipped with various facilities such as a mini zoo, and a bird park

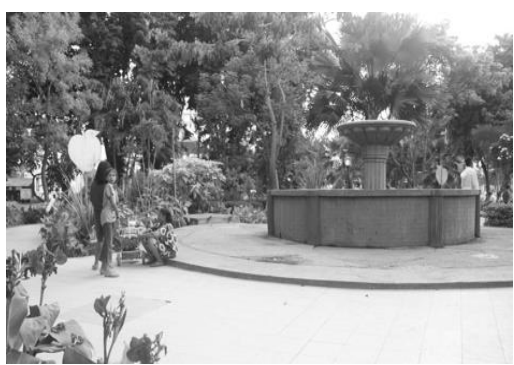

The centre with a fountain

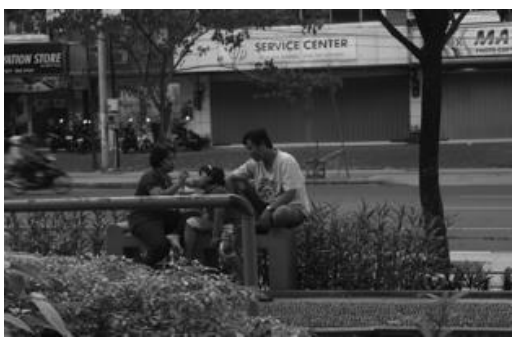

Sitting area

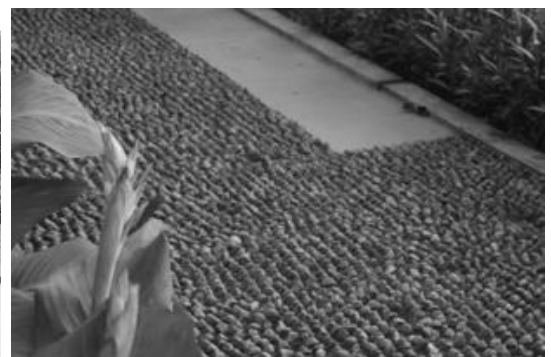

A reflexology footpath

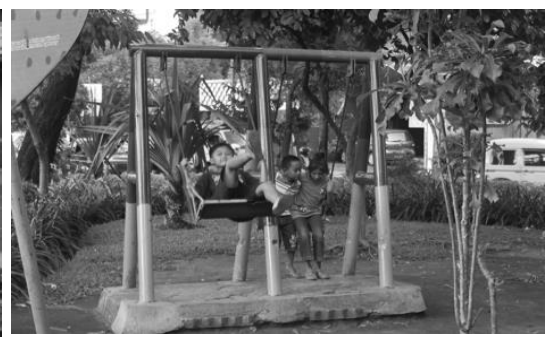

Swings in the playground area

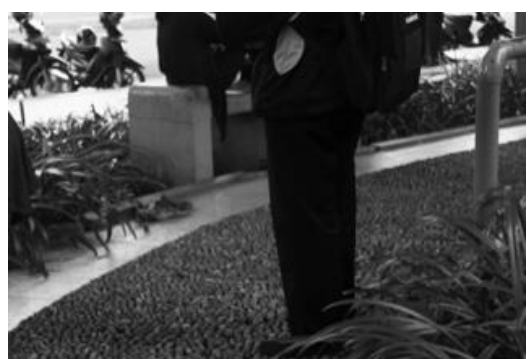

The reflexology footpath

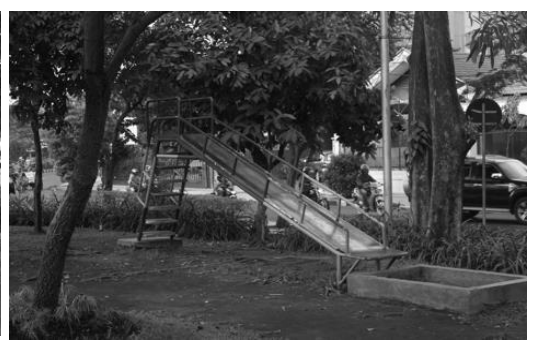

Slidings in the playground area

Figure 3. Elderly Park is equipped with a reflexology footpath and children playground

- The parks are visited by families (54\%) and by individuals along with friends (24\%) for various reasons, such as outdoor recreations (44\%), scenic and visual enjoyment (26\%), and meeting friends $(22 \%)$.

- The visitors are mostly from nearby communities of the parks as indicated by $60 \%$ of the respondents reaching the parks within 10-15 minutes on foot (26\%), and the majority of the visitors (72\%) used motorbikes to the parks (figure 6).

\section{The Parks for Everyone}

In term of socio-economic position, the visitors of the parks are commoners with diverse backgrounds referring to (figure7):

- The majority are women (58\%) as 'the marginal group', and $42 \%$ are men

- Children (8\%) as 'the silent group,' and elderly $(4 \%)$ as 'the forgotten' group, adult ( $8 \%)$, and the majority are teens (40\%), and youth (40\%). 


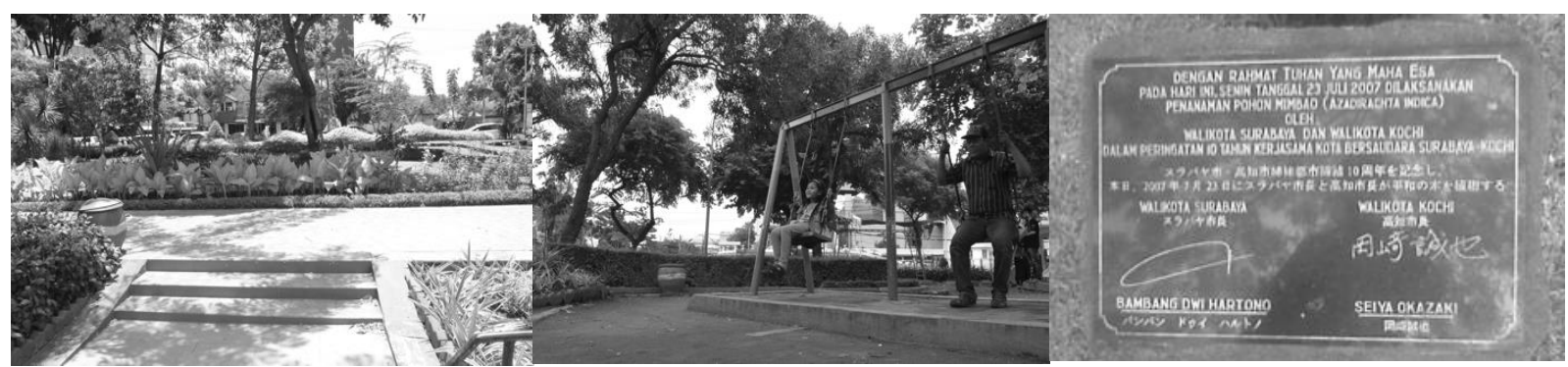

The pedestrian pathway

A swing in the playground

A plaque of a frienship tree

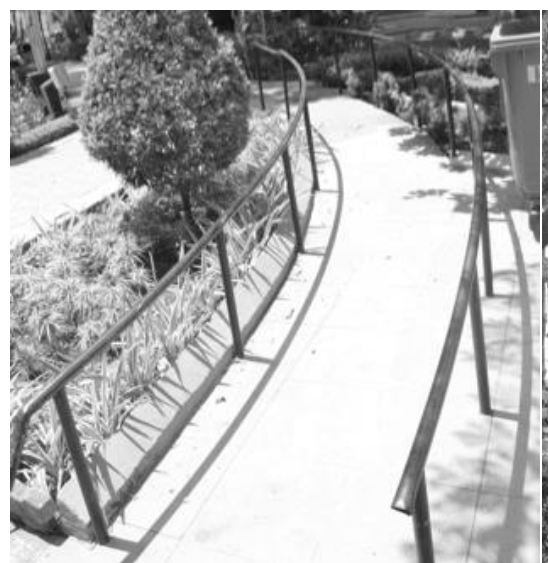

A passageway for disable people

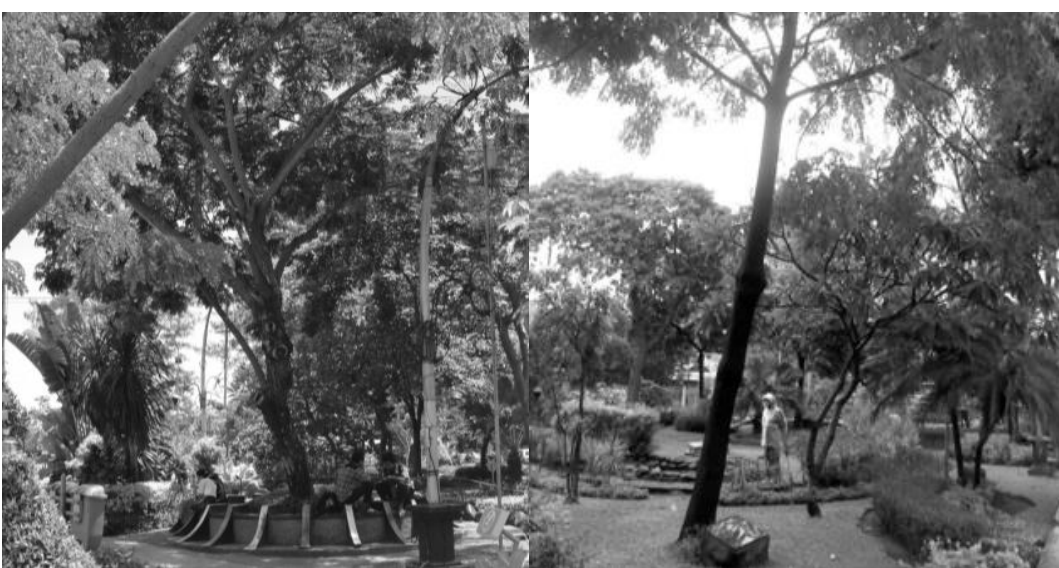

Seatting area with trees
The friendship tree, a mimbao tree

Figure 4. Friendship park is equipped with passageway for disable people and children playground

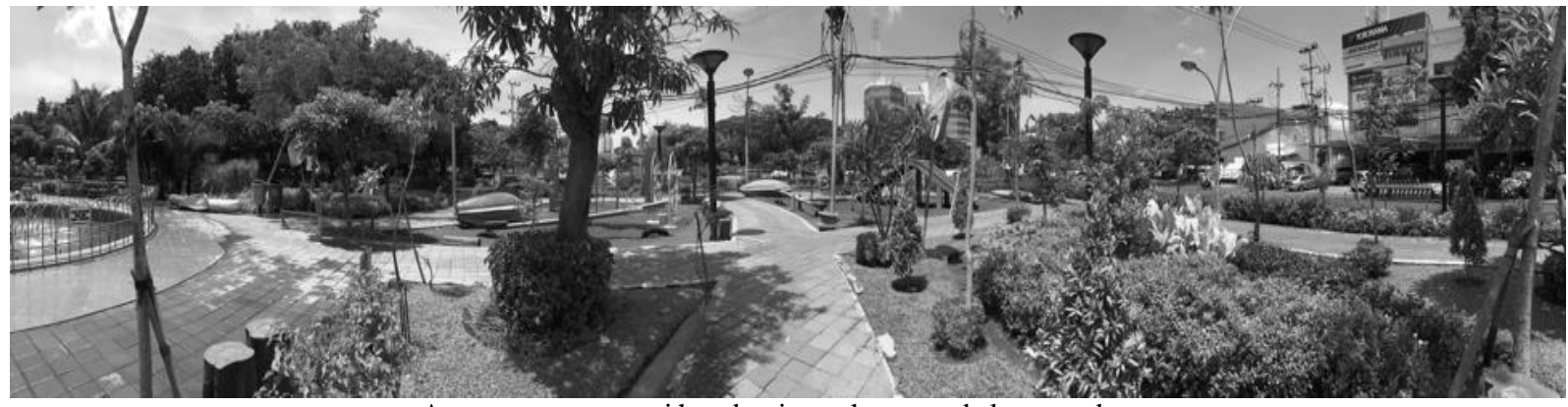

A green open space with pedestrian pathways and playground area

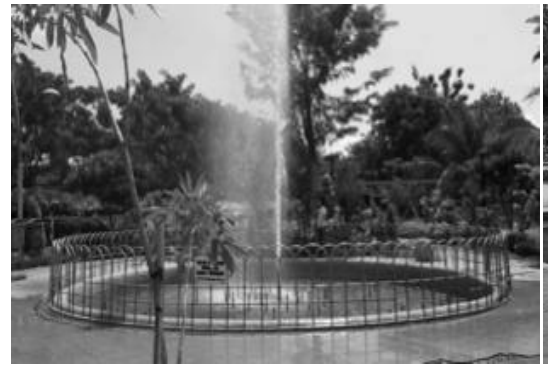

A fountain in the Centre of the park

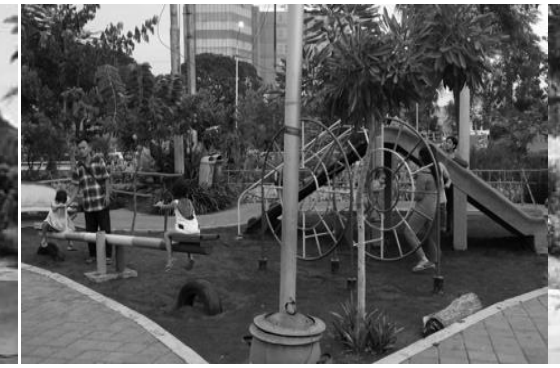

Sliding in the playground area

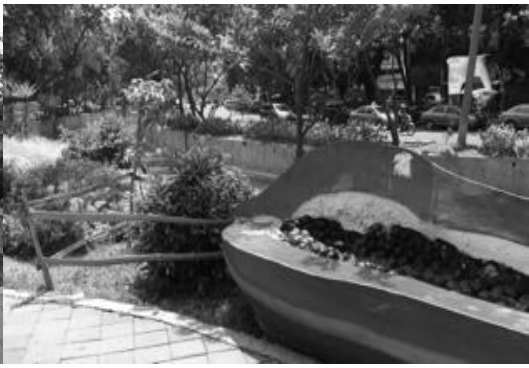

Seats in papaya form

Figure 5. Fruity park is equipped with pedestrian pathways and children playground

- Senior high school (48\%) and university student $(24 \%)$;

- Unemployed or students (30\%), assistants professional (26\%), housewives (20\%), blue-collar workers $(10 \%)$, retired persons $(6 \%)$ and some (4\%) professional workers (figure 7).

\section{The People's Perception of the Parks}

According to the people's perception of the five parks, most of the visitors perceived (figure 8):

- In term of aesthetic: the parks are clean (74\%), gorgeous $(78 \%)$; 


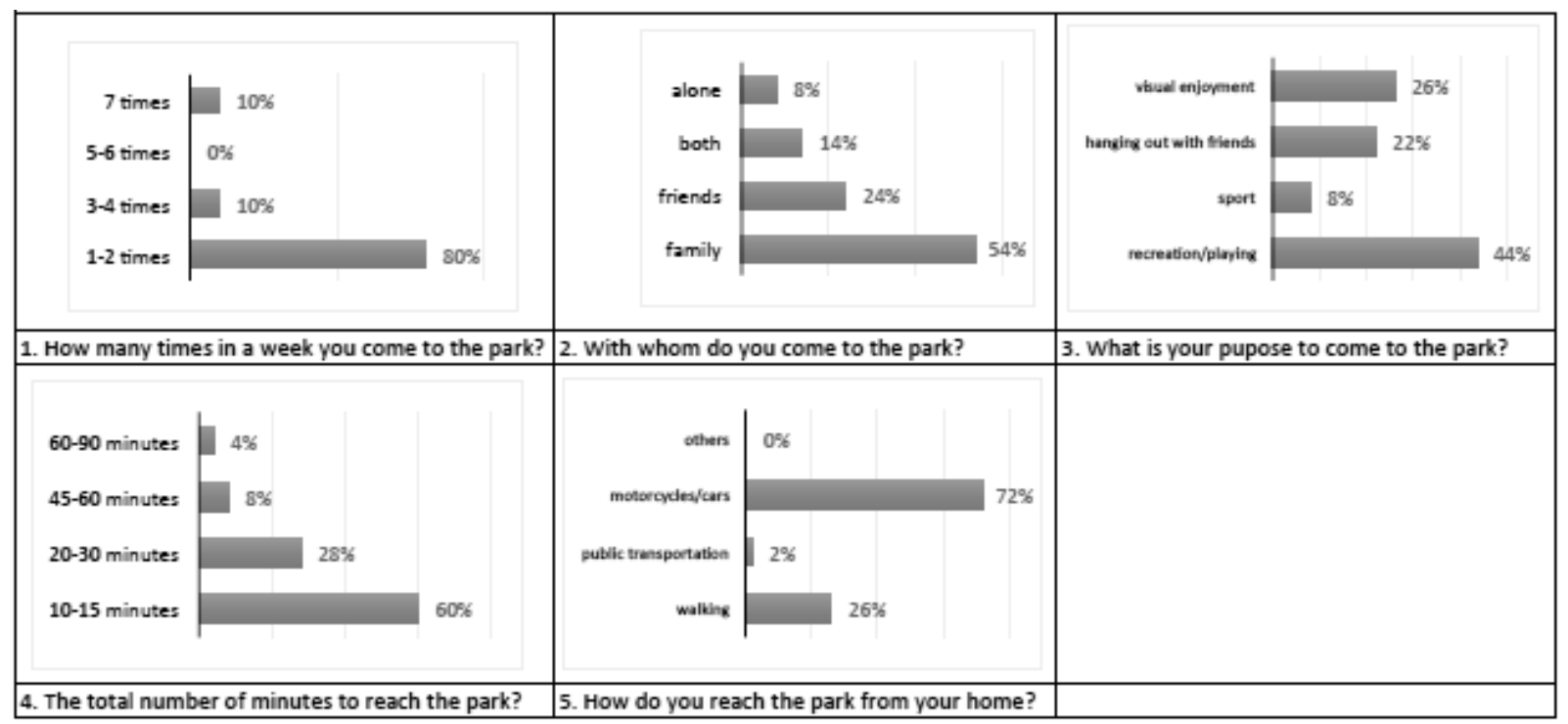

Figure 6. Survey results on the purposes, accessibility and travel time to the urban parks in Surabaya

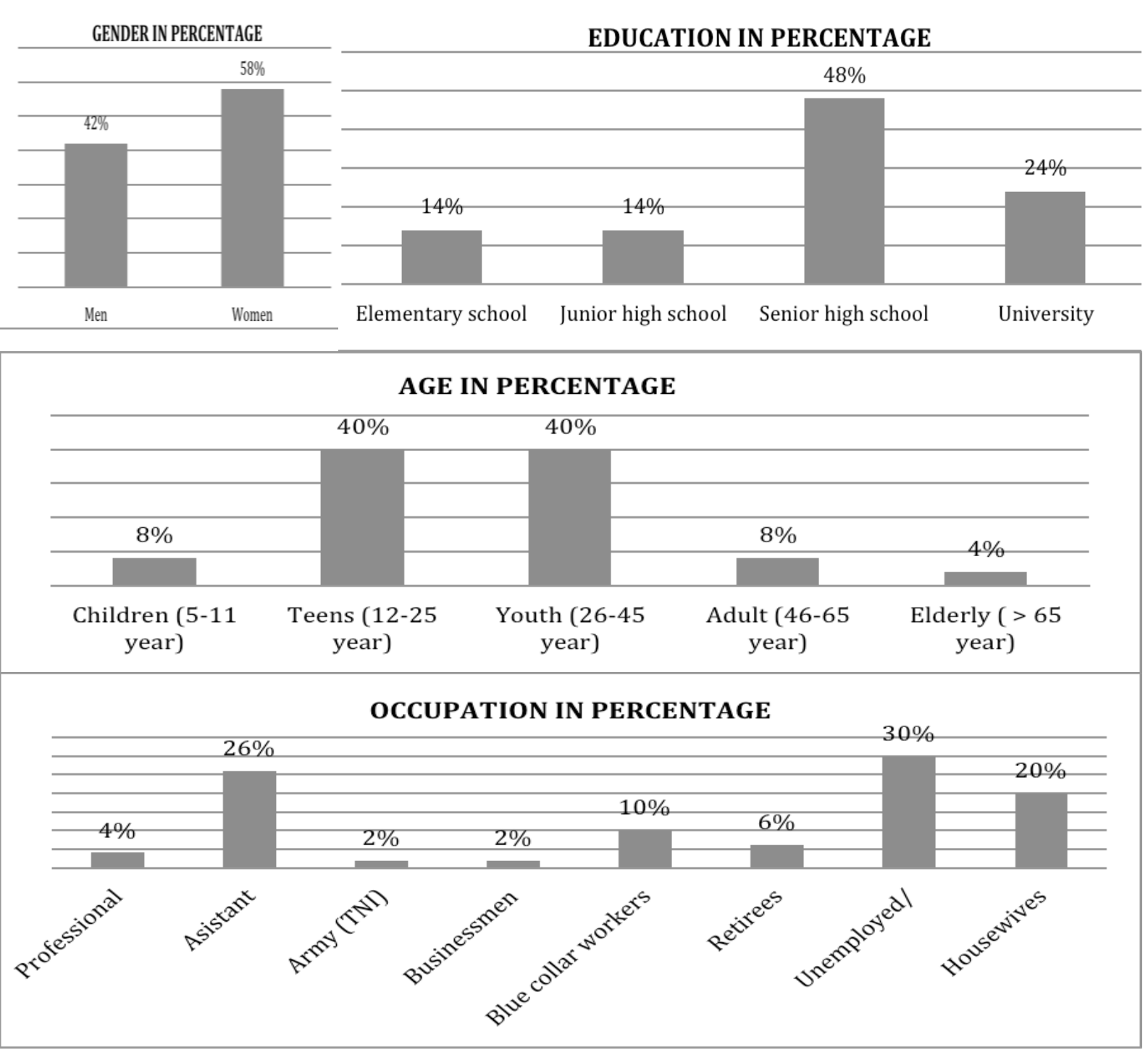

Figure 7. Survey results on the socio-economic position of the visitors to the urban parks in Surabaya 
- In term of functions: the parks are save (76\%), and adequate provision of amenities (66\%).

- Amenities in the parks are the main reason for most of the people come to the parks (52\%), and some of them for scenic enjoyment (36\%).

- Which amenity is preferred by the visitors, many of them enjoy the playgrounds (44\%), some sitting areas $(26 \%)$, and only few enjoy (10\%) the sport facilities. It is comprehended that the playgrounds is the most important amenity in the parks that conform with the majority of the visitors were families (54\%), and many of the visitors (44\%) of the respondents came for recreation.

- Finally, most of the visitors (78\%) perceived the parks are good places to be visited. To improve the quality of the parks for future development, the visitors hope that two items have to be improved such as amenities (54\%) namely playgrounds for children, and aesthetic of the parks (24\%) namely greenery landscape.

Overall among the five parks in Surabaya (figure 9), Bungkul Park is the best park as 50\% of the respondents perceived it as a very good park and another $50 \%$ perceived the park as a good park. This perception on the park as the best park is confirmed with the fact that the park is the winner of the best city park in Asia for 'the 2013 Townscape Award' (ATA) awarded by the United Nation. Consecutively, the second best park perceived by the visitors is Friendship park, as $20 \%$ of the respondents perceived it as a very good park and another $80 \%$ perceived the park as a good park. The third best park perceived by the visitors is Flora park as $10 \%$ of the respondents perceived it as a very good park and another $90 \%$ perceived the park as a good park. The fourth ranking is Elderly Park, as $10 \%$ of the respondents perceived it as a very good park and another $80 \%$ perceived the park as a good park. The last one is Fruity Park, as $90 \%$ of the respondents perceived it as a good park and another $10 \%$ perceived the park as a bad park.

\section{CONCLUSION}

We started this paper with an assertion that prior to our work there had been no information of the urban parks in Surabaya that could be used to improve visual environmental quality of the urban parks. What we hope to have shown with this study is that data on the perceptions of visitors of the parks is informed. The study shows that since the construction of the parks in 2007, the city of Surabaya under the

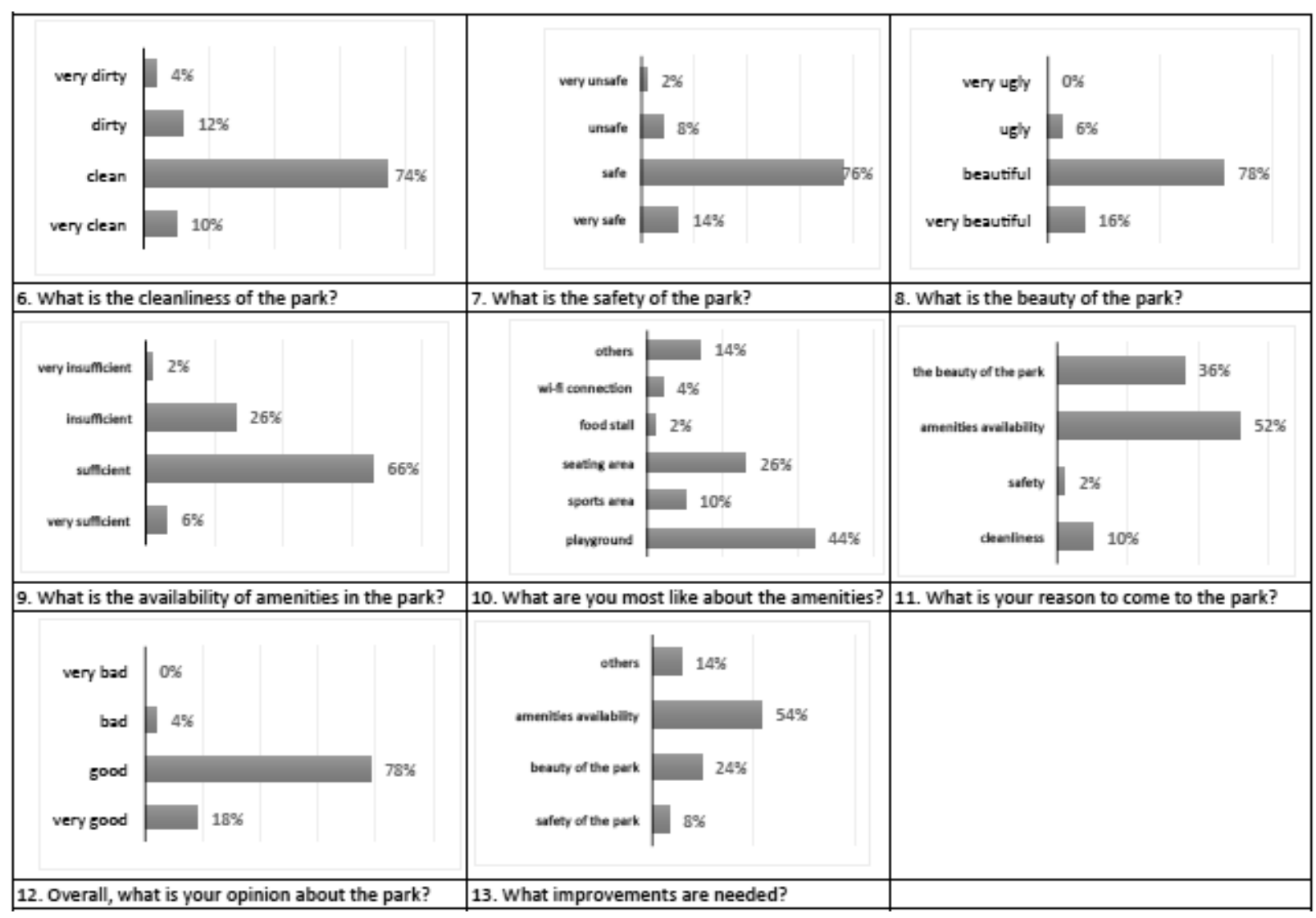

Figure 8. Survey results on the people's perception on the condition of the urban parks in Surabaya 


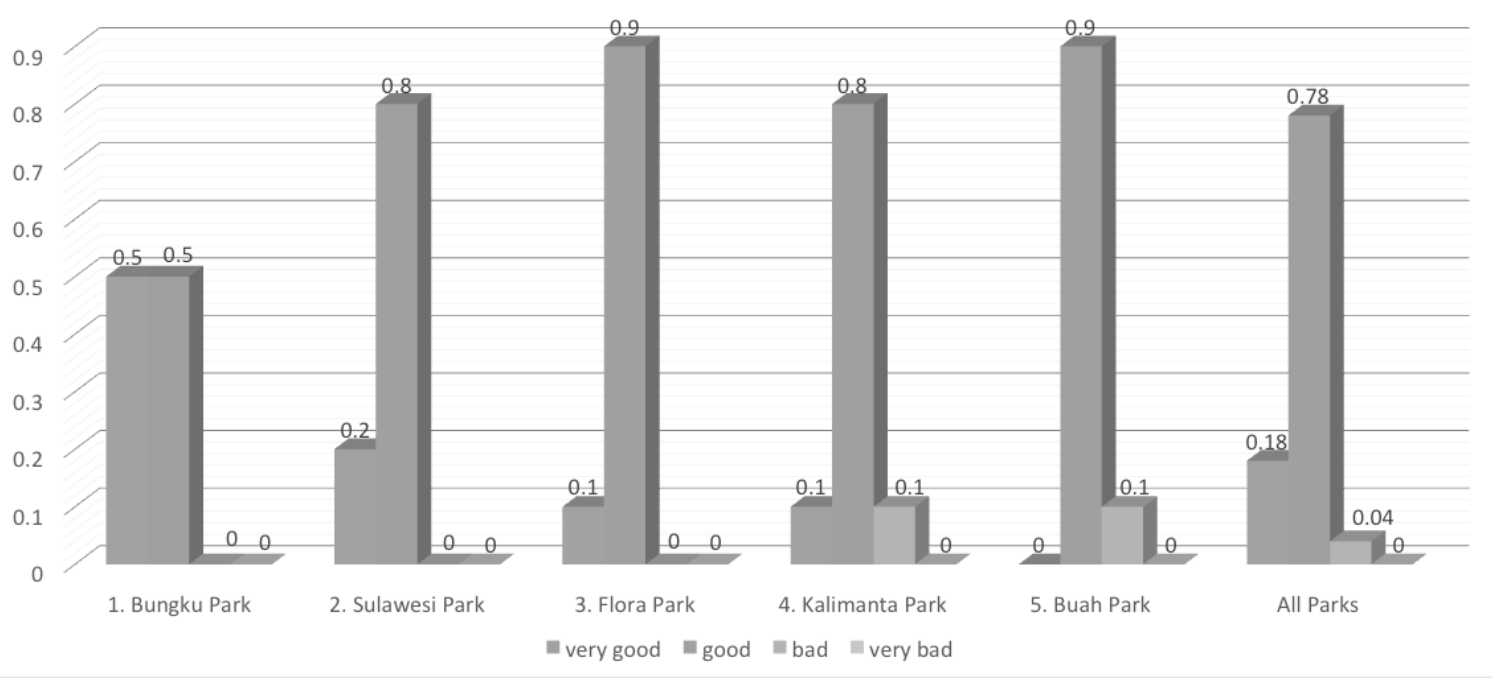

Figure 9. Ranking of all parks based on the visitors' perceptions

Department of Parks and Cleanliness has transformed urban open spaces into active urban open spaces that equipped with playground, sport areas, pedestrian pathways, seating areas, mini zoo, and even a mini bird park.

As discussed in the previous section, emphatic urban parks are parks for every person, in the case of the active urban parks in Surabaya were accessed by diverse backgrounds of visitors, such as:

1. People of all ages, such as children $(8 \%)$ as 'the silent group,' and elderly (4\%) as 'the forgotten' group, adult (8\%), teens (40\%), and youth (40\%).

2. People in all socio-economic positions, the park is a symbol of equality, since no differences are made between rich and poor, as most of the visitors to the parks are the common people, such as unemployed (30\%), assistant professionals (26\%), house wives $(20 \%)$, blue-collar workers $(10 \%)$, retired persons $(6 \%)$, and professional workers $(4 \%)$. Those average income people that tend to be less active in their leisure time because they are less able to afford and access leisure facilities, thus the free access parks have provide them a place to enjoy recreational and physical activities.

3. People with disabilities, they are often less physically active than those without a disability, hence physical activity is vital for people with disabilities. Increase access to these active parks for the disable people is an emphatic action for the disadvantaged people, such as the Bungkul Park, and the Elderly Park.

4. People of 'the marginal group' as the majority of the visitors who are women $(58 \%)$, and the remaining visitors are men $(42 \%)$.
In term of uses, the active urban parks are designed towards the need of the public that aims at promoting physical activity for people. The result of the study shows that the need of most of the visitors is amenities. Amenities in the parks are the main reason for most of the people to come to the parks (52\%), and many of them enjoy the playgrounds (44\%), and some seating areas (26\%). In this sense, these amenities of the urban parks provide citizens with opportunities to socialize and enjoy active recreational activities outdoors. For future improvement, the amenities are also the main issue mentioned by the visitors (54\%) that need to be upgraded.

At last, the provision of the active urban parks in Surabaya can be comprehended from the perception of the people. The result of the surveys showed that most of the visitors perceived the five parks are clean (74\%), and gorgeous (78\%); save (76\%), and adequate provision of amenities $(66 \%)$.

\section{ACKNOWLEDGEMENTS}

I gratefully acknowledge the Ministry of National Education of the Republic of Indonesia for the financial support of my research, as this paper is the result of the research.

\section{REFERENCES}

Badshah, A.A. (1996). Our Urban Future, New Paradigms for Equity and Sustainability. London \& New Jersey: Zed Books Ltd.

Carr, S. et al. (1992). Public Space. New York: Van Nostrand Reinhold Company. 
Creswell, J.W. (2007). Qualitative Inquiry and Research Design: Choosing Among Five Approaches. Thousand Oaks, CA: Sage Publication, Inc.

Edwards, P. \& Tsouros, A. (2006). Promoting physical activity and active living in urban environments: the role of local governments. World Health Organization.

Gibson, J.J. (1972). "A Theory of Direct Visual Perception", in J. Royce, W. Rozenboom (eds.). The Psychology of Knowing. New York: Gordon \& Breach.
Gibson, J.J. (1966). The Senses Considered as Perceptual Systems. Boston: Houghton Mifflin.

Halim, D. (2005). Psikologi Arsitektur, Pengantar Kajian Lintas Disiplin. Jakarta: Grasindo.

http://www.dkp-surabaya.org/2011/01/taman-bungkul.jsp. Accessed May 28, 2014.

http://pkbl.bumn.go.id/index/detail/id/198. Accessed May 28, 2014.

Kwanda, T., Kartono, L. \& Wonoseputro, C. (2014). Kajian Persepsi Masyarakat Terhadap Ruang Kota di Surabaya, Malang, dan Yogyakarta. Surabaya: LPPM, Universitas Kristen Petra. 